\title{
Study of an Amorphous Silicon Oxide Buffer Layer for p-Type Microcrystalline Silicon Oxide/n-Type Crystalline Silicon Heterojunction Solar Cells and Their Temperature Dependence
}

\author{
Taweewat Krajangsang, ${ }^{1}$ Apichan Moollakorn, ${ }^{1}$ Sorapong Inthisang, \\ Amornrat Limmanee, ${ }^{1}$ Kobsak Sriprapha, ${ }^{1}$ Nattaphong Boriraksantikul, ${ }^{2}$ \\ Tianchai Taratiwat, ${ }^{2}$ Nirod Akarapanjavit, ${ }^{2}$ and Jaran Sritharathikhun ${ }^{1}$ \\ ${ }^{1}$ Solar Energy Technology Laboratory (STL), National Electronics and Computer Technology Center (NECTEC), \\ Pathumthani 12120, Thailand \\ ${ }^{2}$ PTT Research \& Technology Institute, PTT Public Company Limited, Phra Nakhon Si Ayutthaya 13170, Thailand \\ Correspondence should be addressed to Taweewat Krajangsang; taweewat.krajangsang@nectec.or.th
}

Received 6 May 2014; Revised 17 August 2014; Accepted 18 August 2014; Published 28 August 2014

Academic Editor: Niyaz Mohammad Mahmoodi

Copyright (C) 2014 Taweewat Krajangsang et al. This is an open access article distributed under the Creative Commons Attribution License, which permits unrestricted use, distribution, and reproduction in any medium, provided the original work is properly cited.

\begin{abstract}
Intrinsic hydrogenated amorphous silicon oxide ( $\mathrm{i}-\mathrm{a}-\mathrm{SiO}: \mathrm{H})$ films were used as front and rear buffer layers in crystalline silicon heterojunction (c-Si-HJ) solar cells. The surface passivity and effective lifetime of these $\mathrm{i}$-a-SiO:H films on an n-type silicon wafer were improved by increasing the $\mathrm{CO}_{2} / \mathrm{SiH}_{4}$ ratios in the films. Using i-a-SiO:H as the front and rear buffer layers in c-Si-HJ solar cells was investigated. The front $\mathrm{i}$-a-SiO:H buffer layer thickness and the $\mathrm{CO}_{2} / \mathrm{SiH}_{4}$ ratio influenced the open-circuit voltage $\left(V_{\text {oc }}\right)$, fill factor (FF), and temperature coefficient (TC) of the c-Si-HJ solar cells. The highest total area efficiency obtained was $18.5 \%$ $\left(V_{\mathrm{oc}}=700 \mathrm{mV}, J_{\mathrm{sc}}=33.5 \mathrm{~mA} / \mathrm{cm}^{2}\right.$, and $\left.\mathrm{FF}=0.79\right)$. The TC normalized for this c-Si-HJ solar cell efficiency was $-0.301 \% /{ }^{\circ} \mathrm{C}$.
\end{abstract}

\section{Introduction}

High-efficiency solar cells with low production costs are still needed for manufacturers. Generally, operating a solar cell in a high-temperature environment degrades its conversion efficiency [1-4]. Therefore, developing solar cells for use in tropical regions is important. Crystalline silicon heterojunction (c-Si-HJ) solar cells with ultrathin intrinsic hydrogenated amorphous silicon (i-a-Si:H) passivation layers are an attractive crystalline silicon solar cell technology because they have low temperature coefficients (TCs) and high efficiencies [5-7]. However, light absorption lost to the hydrogenated amorphous silicon (a-Si:H) window layer lowers the short circuit current $\left(J_{\mathrm{sc}}\right)$ and solar cell performance. Using wide bandgap materials is a potential solution to this problem. Hydrogenated silicon oxide is a good candidate for the window layer material because hydrogenated amorphous silicon oxide (a-SiO:H) exhibited excellent passivation [8-10].
Furthermore, hydrogenated microcrystalline silicon oxide ( $\mu \mathrm{c}-\mathrm{SiO}: \mathrm{H})$ exhibited better electrical properties and lower optical absorption coefficients than a-Si:H [11-14]. Thus, combining a-SiO:H and $\mu \mathrm{c}-\mathrm{SiO}: \mathrm{H}$ for the heterojunction solar cell window layer is promising. In this paper, we investigated the effect that using intrinsic hydrogenated amorphous silicon oxide (i-a-SiO:H) films with wide optical bandgaps as the buffer layers had on p-type hydrogenated microcrystalline silicon oxide (p- $\mu \mathrm{c}-\mathrm{SiO}: \mathrm{H}) / \mathrm{c}-\mathrm{Si}-\mathrm{HJ}$ solar cell performance at high operating temperatures.

\section{Experimental Details}

2.1. Deposition of $i-a-S i O: H$ Films. The $\mathrm{i}-\mathrm{a}-\mathrm{SiO}: \mathrm{H}$ films were prepared on soda-lime glass substrates and float-zone (FZ) silicon wafers (100) using $\mathrm{n}$-type $1-5 \Omega \mathrm{cm}$ double side polished wafers $260-300 \mu \mathrm{m}$ thick. Prior to the deposition, the 
TABle 1: Deposition conditions for the i-a-SiO:H films.

\begin{tabular}{lc}
\hline Parameters & Values \\
\hline $\mathrm{H}_{2} / \mathrm{SiH}_{4}$ & 3.3 \\
$\mathrm{CO}_{2} / \mathrm{SiH}_{4}$ & $0-0.5$ \\
Plasma frequency & $60 \mathrm{MHz}$ \\
Deposition temperature & $180^{\circ} \mathrm{C}$ \\
Deposition pressure & $300 \mathrm{mTorr}$ \\
Power density & $20 \mathrm{~mW} / \mathrm{cm}^{2}$ \\
Thickness & $50 \mathrm{~nm}$ \\
\hline
\end{tabular}

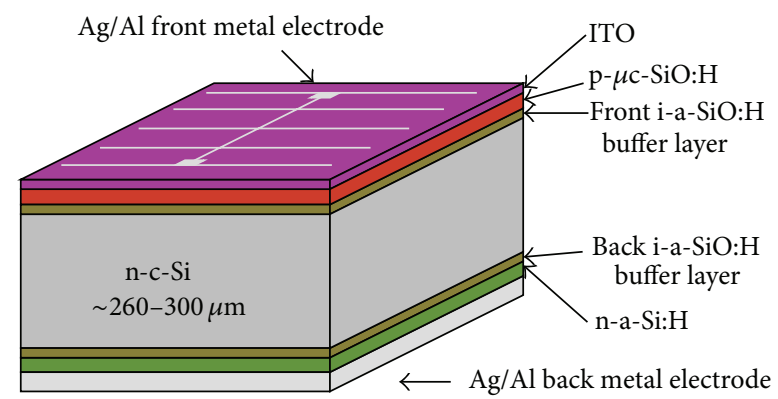

FIGURE 1: Schematic diagram of c-Si-HJ solar cells.

wafers were cleaned (ethanol/acetone/ethanol: 15/15/15 min) and dipped into diluted 5\% hydrofluoric acid (HF) to remove any native oxide before depositing the $\mathrm{i}-\mathrm{a}-\mathrm{SiO}: \mathrm{H}$ films. The i-a-SiO:H films were deposited via a $60 \mathrm{MHz}$ very high frequency plasma enhanced chemical vapor deposition (VHF-PECVD) in a multichamber with a parallel plate configuration. We used silane $\left(\mathrm{SiH}_{4}\right)$, hydrogen $\left(\mathrm{H}_{2}\right)$, and carbon dioxide $\left(\mathrm{CO}_{2}\right)$ as the reactant gases. The substrate temperature, plasma power density, and deposition pressure were held at $180^{\circ} \mathrm{C}, 20 \mathrm{~mW} / \mathrm{cm}^{2}$ and $300 \mathrm{mTorr}$, respectively. The deposition conditions are summarized in Table 1. Afterwards, the effects of the $\mathrm{CO}_{2} / \mathrm{SiH}_{4}$ ratio on the film properties were investigated. The $\mathrm{i}-\mathrm{a}-\mathrm{SiO}: \mathrm{H}$ film passivation quality was characterized using the quasi-steady-state photoconductance (QSSPC) lifetime $[15,16]$. The lifetime samples were deposited as i-a-SiO:H films on both sides of the n-c-Si wafer, and their passivation quality was measured in terms of the effective lifetime $\left(\tau_{\text {eff }}\right)$. The optical properties and thickness of these $\mathrm{i}-\mathrm{a}-\mathrm{SiO}: \mathrm{H}$ films coated on soda-lime glass substrates were evaluated via spectroscopic ellipsometry (SE).

2.2. Fabrication of Heterojunction Solar Cells. Crystalline silicon heterojunction solar cells were fabricated with i-a$\mathrm{SiO}: \mathrm{H}$ buffer layers. To investigate the effect the front $\mathrm{i}$ a-SiO:H buffer layer had on the solar cell performance, c-Si-HJ solar cells were fabricated with $\mathrm{Al} / \mathrm{Ag} / \mathrm{ITO} / \mathrm{p}-$ $\mu \mathrm{c}-\mathrm{SiO}: \mathrm{H} / \mathrm{i}-\mathrm{a}-\mathrm{SiO}: \mathrm{H} / \mathrm{n}-\mathrm{c}-\mathrm{Si} / \mathrm{i}-\mathrm{a}-\mathrm{SiO}: \mathrm{H} / \mathrm{n}-\mathrm{a}-\mathrm{Si}: \mathrm{H} / \mathrm{Ag} / \mathrm{Al}$ structure. The schematic diagram of the c-Si-HJ solar cells is shown in Figure 1. The p- $\mu \mathrm{c}-\mathrm{SiO}: \mathrm{H}$ window layer was doped with 3\%-hydrogen-diluted trimethylboron (TMB: $\mathrm{B}\left(\mathrm{CH}_{3}\right)_{3}$ ) and deposited via $40 \mathrm{MHz}$ VHF-PECVD. Additionally, the aSi:H n-layer was doped with 3\%-hydrogen-diluted phosphine $\left(\mathrm{PH}_{3}\right)$ and prepared via $60 \mathrm{MHz}$ VHF-PECVD. An indium tin oxide (ITO) was used as the transparent conducting oxide (TCO) and as the antireflection coating layer and was deposited via radio frequency magnetron sputtering. The front and back metal electrodes were evaporated using thermal boat sources with silver and aluminum pallet sources. The $\tau_{\text {eff }}$ of the solar cells was evaluated from the photoconductance decay before depositing the ITO and metal electrodes. The photovoltaic parameters (PV) of the solar cells were investigated under standard conditions (AM $1.5,100 \mathrm{~mW} / \mathrm{cm}^{2}$, and $25^{\circ} \mathrm{C}$ ) using a double light source solar simulator. The total solar cell area was $1 \mathrm{~cm}^{2}$. The quantum efficiency $(\mathrm{QE})$ of the solar cells was characterized using the spectral response measurements. To determine the temperature dependence of the solar cell performance, we measured the solar cell parameters using a solar simulator on a probe station at ambient temperatures $(T)$ ranging from $25^{\circ} \mathrm{C}$ to $65^{\circ} \mathrm{C}$ with a step increment of $10^{\circ} \mathrm{C}$ under 1-sun irradiation. The TC value can be expressed as follows:

$$
\mathrm{TC}\left(\text { part } /{ }^{\circ} \mathrm{C}\right)=\frac{1}{Z} \times\left.\left(\frac{\delta Z}{\delta T}\right)\right|_{T_{n=25^{\circ} \mathrm{C}}},
$$

where $Z$ means the solar cell parameters of efficiency $(\eta)$, open-circuit voltage $\left(V_{\mathrm{oc}}\right), J_{\mathrm{sc}}$, and fill factor $(\mathrm{FF})$. A normalized temperature $\left(T_{n}\right)$ of $25^{\circ} \mathrm{C}$ was chosen because it corresponds to the standard test solar cell measurement conditions.

\section{Results and Discussion}

3.1. Properties of the i-a-SiO:H Films. The effects the $\mathrm{CO}_{2} / \mathrm{SiH}_{4}$ ratio had on the surface passivation quality and optical properties of the $\mathrm{i}-\mathrm{a}-\mathrm{SiO}: \mathrm{H}$ films were investigated. $\mathrm{CO}_{2}$ was used as $\mathrm{O}$ source gas during the $\mathrm{i}-\mathrm{a}-\mathrm{SiO}: \mathrm{H}$ film deposition. The samples were prepared by increasing the $\mathrm{CO}_{2} / \mathrm{SiH}_{4}$ ratios from 0.0 to 0.50 with a thickness of approximately $50 \mathrm{~nm}$. The samples exhibited an i-aSiO:H $\left(\mathrm{CO}_{2} / \mathrm{SiH}_{4}: 0.0-0.50\right) / \mathrm{n}-\mathrm{c}-\mathrm{Si} / \mathrm{i}-\mathrm{a}-\mathrm{SiO}: \mathrm{H} \quad\left(\mathrm{CO}_{2} / \mathrm{SiH}_{4}\right.$ : $0.17)$ structure. The $\mathrm{CO}_{2} / \mathrm{SiH}_{4}$ ratio affected the $\tau_{\text {eff }}$ of $\mathrm{n}$ c-Si wafers passivated with $\mathrm{i}-\mathrm{a}-\mathrm{SiO}: \mathrm{H}$ films as shown in Figure 2. The $\tau_{\text {eff }}$ increased with increasing $\mathrm{CO}_{2} / \mathrm{SiH}_{4}$ ratios. For a $\mathrm{CO}_{2} / \mathrm{SiH}_{4}$ ratio of 0.0 , the sample showed a low $\tau_{\text {eff }}$ of $51 \mu \mathrm{s}$ because the i-a-Si:H layer grew epitaxial silicon on the crystalline substrate. The epitaxial interface is a defect and deteriorates the passivation quality. However, the $\tau_{\text {eff }}$ increased rapidly from $232 \mu$ s to $2500 \mu$ s upon increasing the $\mathrm{CO}_{2} / \mathrm{SiH}_{4}$ ratio from 0.17 to 0.50 . Therefore, increasing the $\mathrm{CO}_{2} / \mathrm{SiH}_{4}$ ratio can suppress the epitaxial silicon growth. Meanwhile, the implied $V_{\text {oc }}$ increased from $583 \mathrm{mV}$ to $708 \mathrm{mV}$ with increasing $\mathrm{CO}_{2} / \mathrm{SiH}_{4}$ ratio. In addition, the optical bandgap of the $\mathrm{i}$-a-SiO:H films increased gradually with increasing $\mathrm{CO}_{2} / \mathrm{SiH}_{4}$ ratio. The optical bandgap of a conventional i-a-Si: $\mathrm{H}$ film with a $\mathrm{CO}_{2} / \mathrm{SiH}_{4}$ ratio of 0.0 was $1.72 \mathrm{eV}$. Increasing the $\mathrm{CO}_{2} / \mathrm{SiH}_{4}$ ratio from 0.17 to 0.50 increased the optical bandgap of the $\mathrm{i}-\mathrm{a}-\mathrm{SiO}: \mathrm{H}$ films from $1.81 \mathrm{eV}$ to $1.95 \mathrm{eV}$.

3.2. Fabrication of Heterojunction Solar Cells. The effect of the $\mathrm{CO}_{2} / \mathrm{SiH}_{4}$ ratio for the front $\mathrm{i}-\mathrm{a}-\mathrm{SiO}: \mathrm{H}$ buffer layer on the c-Si-HJ solar cell performance was investigated for 

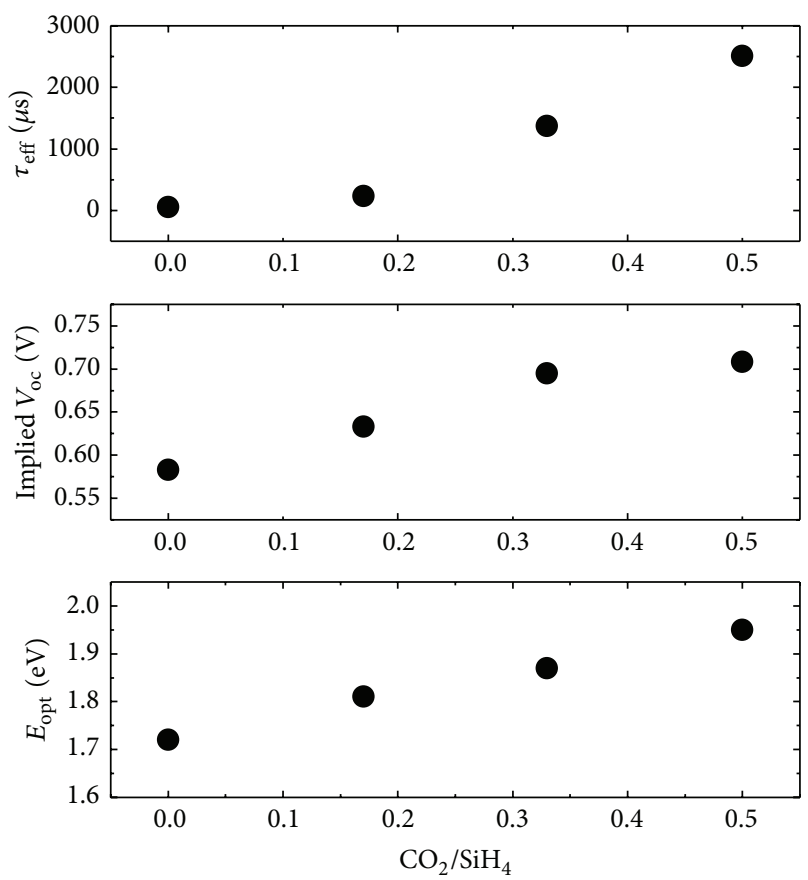

Figure 2: Effective lifetime $\left(\tau_{\text {eff }}\right)$ of $n-c-S i$ passivated by the i-aSiO:H films, which implied that $V_{\text {oc }}$ of the $\mathrm{i}-\mathrm{a}-\mathrm{SiO}: \mathrm{H}$ films and optical bandgap $\left(E_{\mathrm{opt}}\right)$ of the $\mathrm{i}-\mathrm{a}-\mathrm{SiO}: \mathrm{H}$ films are a function of the $\mathrm{CO}_{2} / \mathrm{SiH}_{4}$ ratio.

various $\mathrm{CO}_{2} / \mathrm{SiH}_{4}$ ratios. First, the front i-a-SiO:H buffer layer thickness in the c-Si-HJ solar cell was optimized. The front $\mathrm{i}-\mathrm{a}-\mathrm{SiO}: \mathrm{H}$ buffer layer thickness was varied from $2 \mathrm{~nm}$ to $8 \mathrm{~nm}$. Figure 3 shows the PV parameters and $\tau_{\text {eff }}$ as a function of the $\mathrm{i}-\mathrm{a}-\mathrm{SiO}: \mathrm{H}$ layer thickness. Increasing the front $\mathrm{i}-\mathrm{a}-$ $\mathrm{SiO}: \mathrm{H}$ buffer layer thickness increased the $V_{\mathrm{oc}}$ from $655 \mathrm{mV}$ to $691 \mathrm{mV}$ due to the improved surface passivation. The $\tau_{\text {eff }}$ increased from $586 \mu$ s to $1125 \mu$ s with increasing front buffer thicknesses. A high $V_{\text {oc }}$ of $692 \mathrm{mV}$ and solar cell efficiency of $18.4 \%$ were obtained using the optimized thickness of $6 \mathrm{~nm}$. A front buffer layer thickness below $6 \mathrm{~nm}$ decreased the $V_{\text {oc }}$ of the solar cell. A thicker front buffer layer improved the passivation quality but reduced the FF of the solar cell due to the increased series resistance.

Next, the effect the $\mathrm{CO}_{2} / \mathrm{SiH}_{4}$ ratio of the front i-a$\mathrm{SiO}: \mathrm{H}$ buffer layer had on the solar cell performance was studied. The front $\mathrm{i}$-a-SiO:H buffer layer $\mathrm{CO}_{2} / \mathrm{SiH}_{4}$ ratio was varied from 0.0 to 0.50 while holding the thickness at $6 \mathrm{~nm}$. Figure 4 shows the PV parameters and $\tau_{\text {eff }}$ as a function of the $\mathrm{CO}_{2} / \mathrm{SiH}_{4}$ ratio for the front $\mathrm{i}-\mathrm{a}-\mathrm{SiO}: \mathrm{H}$ buffer layer. The solar cells exhibited a low $V_{\text {oc }}$ of $626 \mathrm{mV}$ at a $\mathrm{CO}_{2} / \mathrm{SiH}_{4}$ ratio of 0.00 due to epitaxial silicon growth $[17,18]$. The $V_{\text {oc }}$ then increased to $699 \mathrm{mV}$ at a $\mathrm{CO}_{2} / \mathrm{SiH}_{4}$ ratio of 0.17 and reduced to $683 \mathrm{mV}$ at a $\mathrm{CO}_{2} / \mathrm{SiH}_{4}$ ratio of 0.50 . The $\tau_{\text {eff }}$ was $1610 \mu$ s for a $\mathrm{CO}_{2} / \mathrm{SiH}_{4}$ ratio of 0.17 and then decreased to $357 \mu \mathrm{s}$ for a $\mathrm{CO}_{2} / \mathrm{SiH}_{4}$ ratio of 0.50 . However, the $\tau_{\text {eff }}$ tended to increase with increasing $\mathrm{CO}_{2} / \mathrm{SiH}_{4}$ ratio as shown in Figure 2. For the solar cell, increasing the $\mathrm{CO}_{2} / \mathrm{SiH}_{4}$ ratio in the front $\mathrm{i}-\mathrm{a}-\mathrm{SiO}: \mathrm{H}$ buffer layer decreased the $V_{\mathrm{oc}}$ and $\mathrm{FF}$ because of the increased series resistance. Figure 5 shows the $\mathrm{I}-\mathrm{V}$ characteristics of c-Si-HJ solar cells with $\mathrm{CO}_{2} / \mathrm{SiH}_{4}$
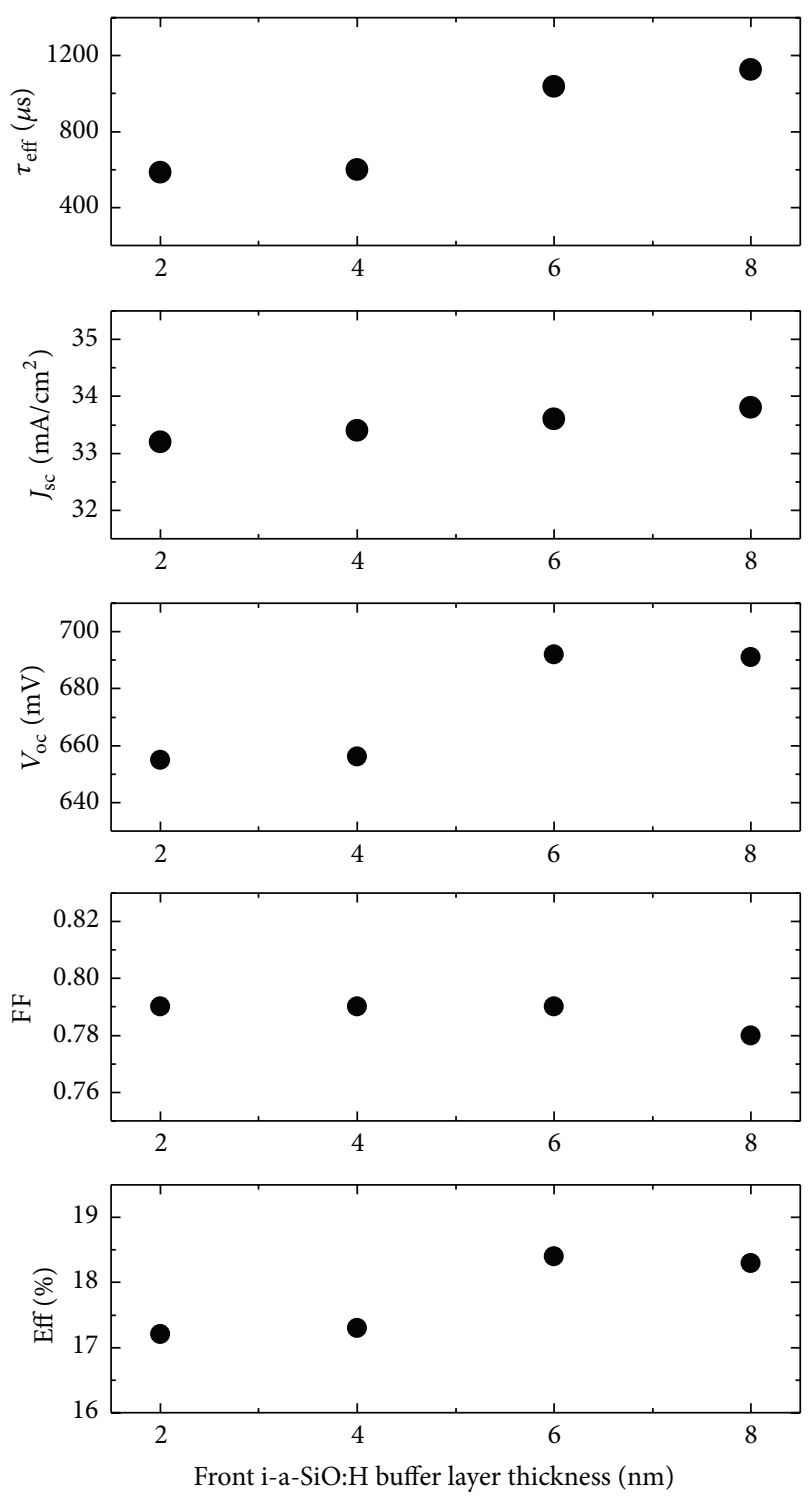

FIgure 3: PV parameters and $\tau_{\text {eff }}$ as a function of front $\mathrm{i}-\mathrm{a}-\mathrm{SiO}: \mathrm{H}$ buffer layer thickness.

ratio in front $\mathrm{i}$-a-SiO:H buffer layer. Increasing the $\mathrm{CO}_{2} / \mathrm{SiH}_{4}$ ratio decreased the $V_{\mathrm{oc}}$ and $\mathrm{FF}$ of $I-V$ curves and showed Sshape influenced from the increased series resistance with the $\mathrm{CO}_{2} / \mathrm{SiH}_{4}$ ratio of 0.50 . These results indicate controlling the $\mathrm{CO}_{2} / \mathrm{SiH}_{4}$ ratio can improve the surface passivation quality and solar cell performance. The spectral response of the solar cells improved with increasing $\mathrm{CO}_{2} / \mathrm{SiH}_{4}$ ratios as shown in Figure 6 because of the increased optical bandgap of the i-a$\mathrm{SiO}: \mathrm{H}$ layer.

The effects the $\mathrm{CO}_{2} / \mathrm{SiH}_{4}$ ratio of the $\mathrm{i}-\mathrm{a}-\mathrm{SiO}: \mathrm{H}$ front buffer layer had on the photovoltaic parameters at various operating temperatures were investigated. Figure 7 presents the normalized solar cell parameters for $\mathrm{c}-\mathrm{Si}-\mathrm{HJ}$ solar cells containing i-a-SiO:H layers with various $\mathrm{CO}_{2} / \mathrm{SiH}_{4}$ ratios measured in the initial state as a function of the operating temperature. The $J_{\mathrm{sc}}$ gradually increased with increasing operating temperature due to the increase in the diffusion 

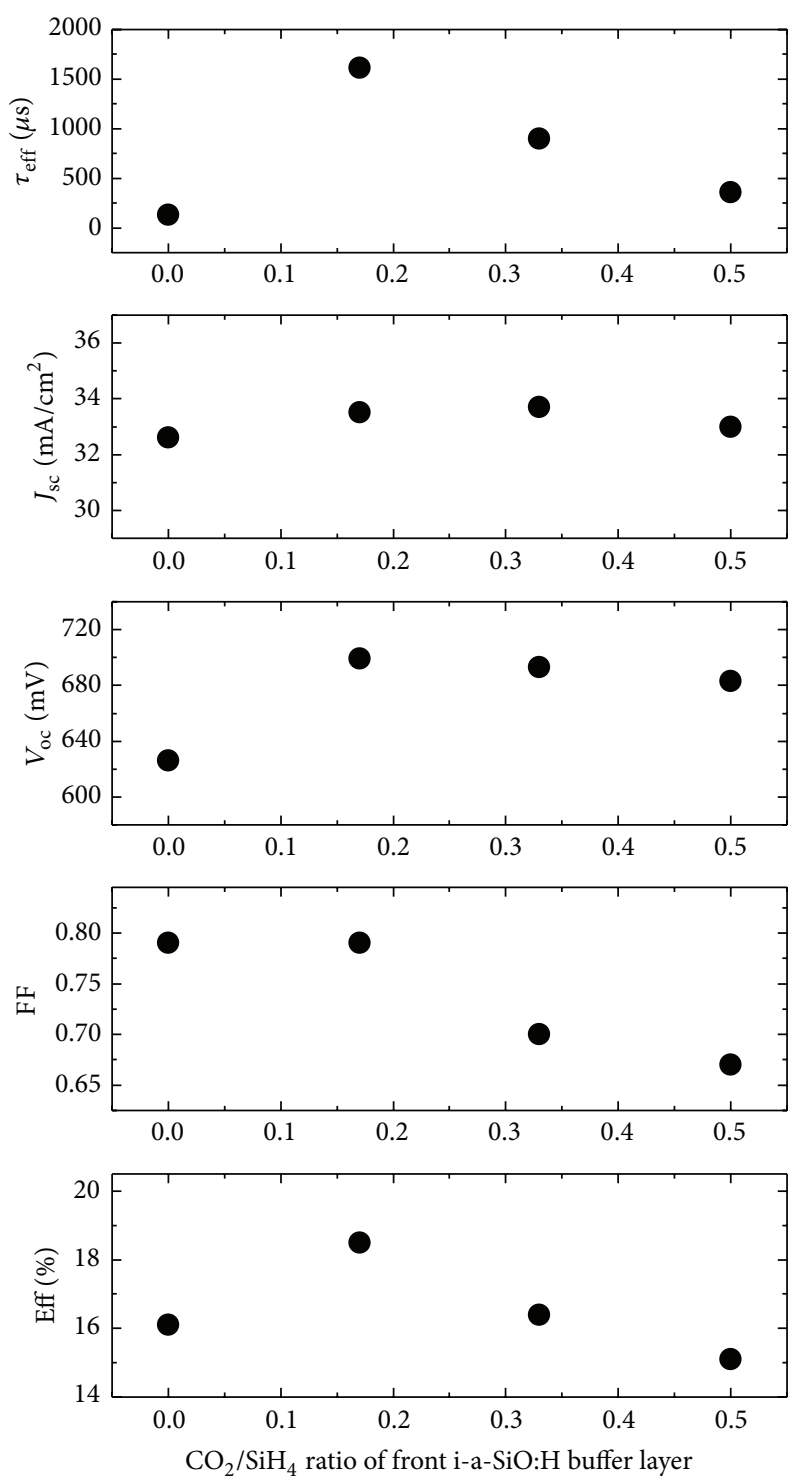

Figure 4: PV parameters and $\tau_{\text {eff }}$ as a function of the $\mathrm{CO}_{2} / \mathrm{SiH}_{4}$ ratio for the front $\mathrm{i}-\mathrm{a}-\mathrm{SiO}: \mathrm{H}$ buffer layer.

length of the minority carriers. The FF and solar cell efficiency decreased with increasing operating temperature due to the significantly reduced $V_{\mathrm{oc}}$. The $V_{\mathrm{oc}}$ decreased with increasing operating temperature because of an increase in the reverse saturation current. The normalized TC for the $V_{\mathrm{oc}}$ of a solar cell with a $\mathrm{CO}_{2} / \mathrm{SiH}_{4}$ ratio of $0,0.08$, and 0.17 in i-a-SiO:H were $-0.318 \% /{ }^{\circ} \mathrm{C},-0.314 \% /{ }^{\circ} \mathrm{C}$, and $-0.290 \% /{ }^{\circ} \mathrm{C}$, respectively. Therefore, the normalized TC for $\eta$ of the solar cell with $\mathrm{CO}_{2} / \mathrm{SiH}_{4}$ ratios of $0,0.08$, and 0.17 in $\mathrm{i}-\mathrm{a}-\mathrm{SiO}: \mathrm{H}$ were $-0.312 \% /{ }^{\circ} \mathrm{C},-0.306 \% /{ }^{\circ} \mathrm{C}$, and $-0.301 \% /{ }^{\circ} \mathrm{C}$, respectively. The experimental results indicate that the $\mathrm{i}-\mathrm{a}-\mathrm{SiO}: \mathrm{H}$ film is a promising buffer layer material for $\mathrm{c}-\mathrm{Si}-\mathrm{HJ}$ solar cells operating at high temperatures.

\section{Conclusions}

We investigated the surface passivation quality of $\mathrm{i}-\mathrm{a}-\mathrm{SiO}: \mathrm{H}$ films for $\mathrm{n}$-type silicon wafers. The $\tau_{\text {eff }}$ improved with

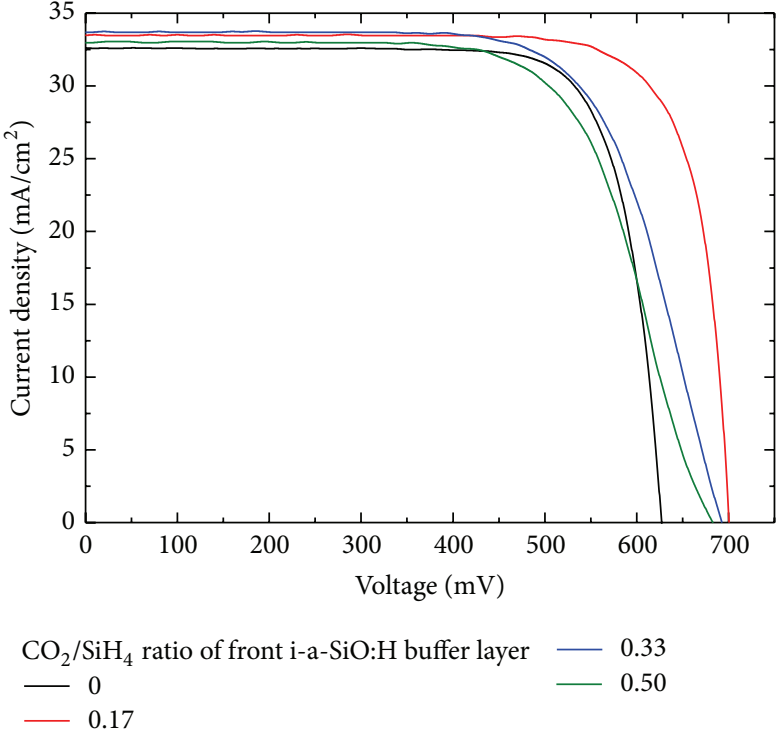

FIgURE 5: $I-V$ characteristics of c-Si-HJ solar cells with $\mathrm{CO}_{2} / \mathrm{SiH}_{4}$ ratio in front $\mathrm{i}-\mathrm{a}-\mathrm{SiO}: \mathrm{H}$ buffer layer.

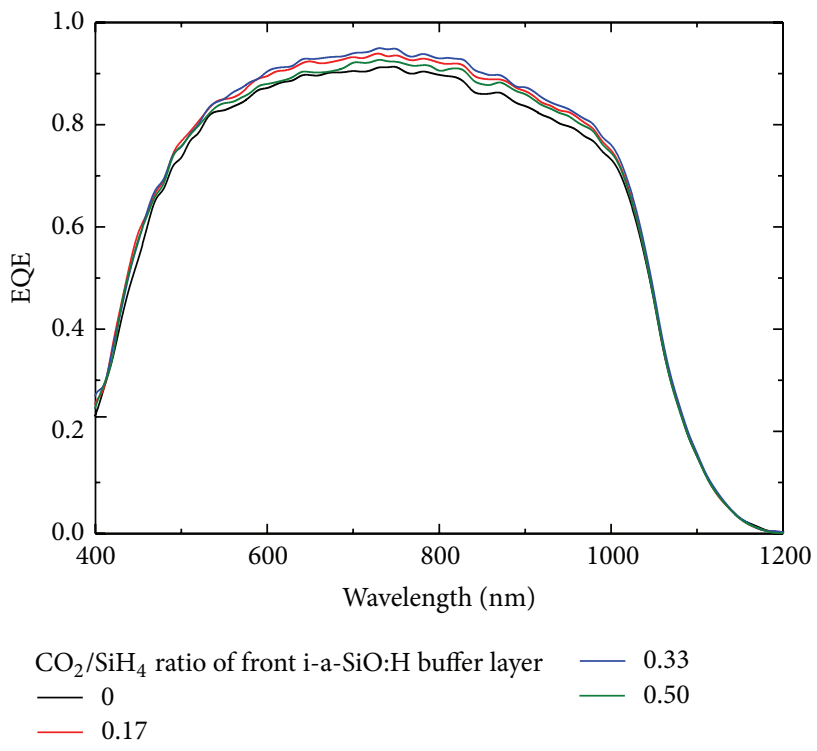

FIGURE 6: Spectral response as a function of the $\mathrm{CO}_{2} / \mathrm{SiH}_{4}$ ratio for the front $\mathrm{i}-\mathrm{a}-\mathrm{SiO}: \mathrm{H}$ buffer layer.

increasing $\mathrm{CO}_{2} / \mathrm{SiH}_{4}$ ratio in the films. We also characterized c-Si-HJ solar cells containing front and rear i-a-SiO:H buffer layers. The thickness and $\mathrm{CO}_{2} / \mathrm{SiH}_{4}$ ratio for the front $\mathrm{i}$-a$\mathrm{SiO}: \mathrm{H}$ buffer layer affected the $V_{\mathrm{oc}}$ and $\mathrm{FF}$ of c-Si-HJ solar cells. Optimized solar cells exhibited better efficiencies with the $\mathrm{i}-\mathrm{a}-\mathrm{SiO}: \mathrm{H}$ front buffer layer than with the $\mathrm{i}-\mathrm{a}-\mathrm{Si}: \mathrm{H}$ front buffer layer. The highest total area efficiency obtained was $18.5 \%\left(V_{\mathrm{oc}}=700 \mathrm{mV}, J_{\mathrm{sc}}=33.5 \mathrm{~mA} / \mathrm{cm}^{2}\right.$, and $\left.\mathrm{FF}=0.79\right)$. The normalized TC for this c-Si-HJ solar cell efficiency was $-0.301 \% /{ }^{\circ} \mathrm{C}$. These experimental results indicate that the $\mathrm{i}-$ a-SiO:H film is a promising buffer layer material for c-Si-HJ solar cells operating at high temperatures. 

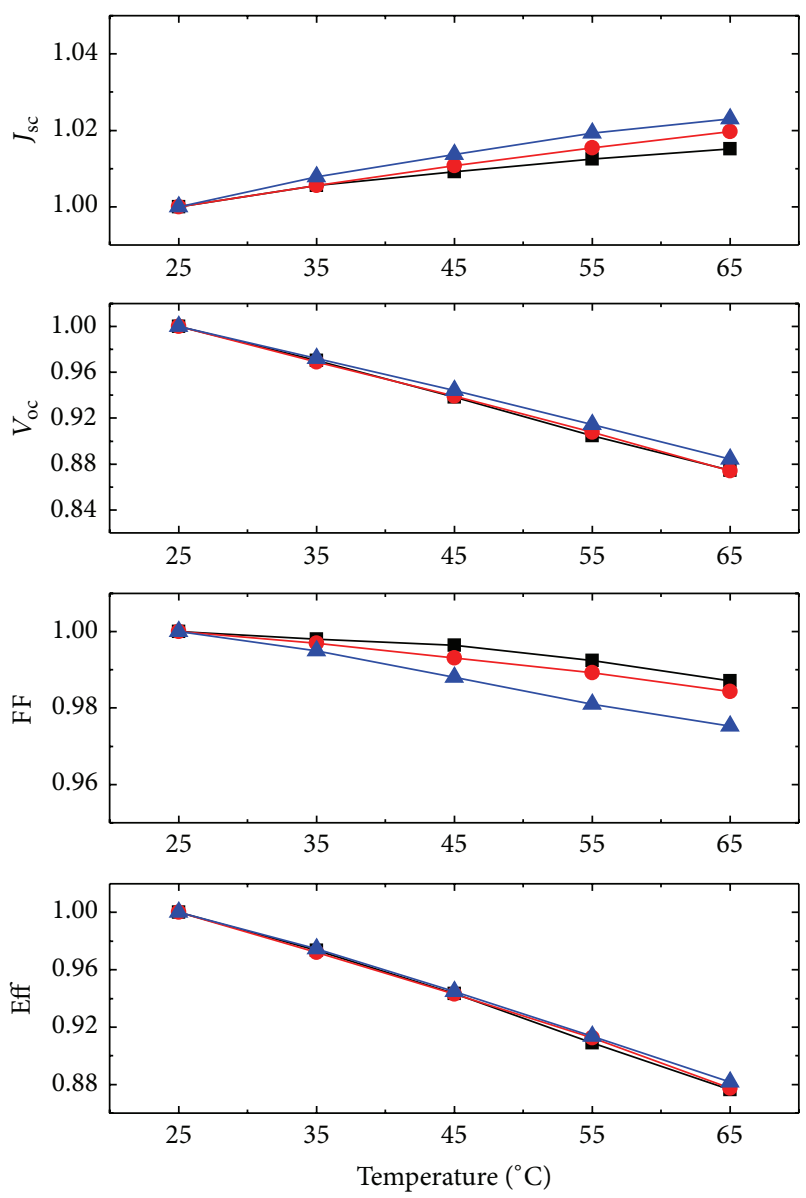

Front $\mathrm{i}-\mathrm{a}-\mathrm{SiO}: \mathrm{H}$ buffer layer $\mathrm{CO}_{2} / \mathrm{SiH}_{4}$ ratio $\longrightarrow 0.08$

FIGURE 7: Normalized solar cell parameters measured in the initial state for the c-Si-HJ solar cells with a $\mathrm{CO}_{2} / \mathrm{SiH}_{4}$ ratio in the front $\mathrm{i}-\mathrm{a}-\mathrm{SiO}: \mathrm{H}$ buffer layers as a function of the operating temperature.

\section{Conflict of Interests}

The authors declare that there is no conflict of interests regarding the publication of this paper.

\section{References}

[1] H. Stiebig, T. Eickhoff, J. Zimmer, C. Beneking, and H. Wagner, "Measured and simulated temperature dependence of aSi:H solar cell parameters," in Proceedings of the MRS Spring Symposium, vol. 420, pp. 855-860, April 1996.

[2] M. Shima, M. Isomura, K. I. Wakisaka, K. Murata, and M. Tanaka, "The influence of operation temperature on the output properties of amorphous silicon-related solar cells," Solar Energy Materials and Solar Cells, vol. 85, no. 2, pp. 167-175, 2005.

[3] M. Taguchi, E. Maruyama, and M. Tanaka, "Temperature dependence of amorphous/crystalline silicon heterojunction solar cells," Japanese Journal of Applied Physics, vol. 47, no. 2, pp. 814-818, 2008.

[4] M. A. Green, "General temperature dependence of solar cell performance and implications for device modelling," Progress in
Photovoltaics: Research and Applications, vol. 11, no. 5, pp. 333340, 2003.

[5] E. Maruyama, A. Terakawa, M. Taguchi et al., "Sanyo's challenges to the development of high-efficiency HIT solar cells and the expansion of HIT business," in Proceedings of the 2006 IEEE 4th World Conference on Photovoltaic Energy Conversion, pp. 1455-1460, May 2006.

[6] J. Damon-Lacoste, P. Roca i Cabarrocas, P. Chatterjee et al., "About the efficiency limits of heterojunction solar cells," Journal of Non-Crystalline Solids, vol. 352, pp. 1928-1932, 2006.

[7] D. L. Bätzner, Y. Andrault, L. Andreetta et al., "Properties of high efficiency silicon heterojunction cells," Energy Procedia, vol. 8, pp. 153-159, 2011.

[8] T. Mueller, S. Schwertheim, and W. R. Fahrner, "Application of wide-bandgap hydrogenated amorphous silicon oxide layers to heterojunction solar cells for high quality passivation," in Proceeding of the 33rd IEEE Photovoltaic Specialists Conference (PVSC '08), pp. 1-6, San Diego, Calif, USA, May 2008.

[9] T. Mueller, S. Schwertheim, M. Scherff, and W. R. Fahrner, "High quality passivation for heterojunction solar cells by hydrogenated amorphous silicon suboxide films," Applied Physics Letters, vol. 92, no. 3, Article ID 033504, 2008.

[10] H. Fujiwara, T. Kaneko, and M. Kondo, "Application of hydrogenated amorphous silicon oxide layers to $c$-Si heterojunction solar cells," Applied Physics Letters, vol. 91, no. 13, Article ID 133508, 2007.

[11] H. Watanabe, K. Haga, and T. Lohner, "Structure of highphotosensitivity silicon-oxygen alloy films," Journal of NonCrystalline Solids, vol. 164-166, no. 2, pp. 1085-1088, 1993.

[12] Y. Matsumoto, F. Meléndez, and R. Asomoza, "Plasma CVD deposited p-type silicon oxide wide-bandgap material for solar cells," Solar Energy Materials and Solar Cells, vol. 52, no. 3-4, pp. 251-260, 1998.

[13] Y. Matsumoto, V. Sánchez, and G. Avila, "Wide optical bandgap p-type $\mu \mathrm{c}$-Si:Ox:H prepared by Cat-CVD and comparisons to p-type $\mu$ c-Si:H," Thin Solid Films, vol. 516, no. 5, pp. 593-596, 2008.

[14] A. Limmanee, T. Sugiura, H. Yamamoto et al., "Boron-doped microcrystalline silicon oxide film for use as back surface field in cast polycrystalline silicon solar cells," Japanese Journal of Applied Physics, vol. 47, no. 12, pp. 8796-8798, 2008.

[15] R. A. Sinton, A. Cuevas, and M. Stuckings, "Quasi-steadystate photoconductance, a new method for solar cell material and device characterization," in Proceedings of the 25th IEEE Photovoltaic Specialists Conference, pp. 457-460, May 1996.

[16] D. H. Neuhaus, P. P. Altermatt, A. B. Sproul et al., "Method for measuring minority and majority carrier mobilities in solar cells wafers passivated with hydrogenated amorphous silicon films," in Proceedings of the 17th European Photovoltaic Solar Energy Conference, pp. 242-245, 2001.

[17] T. H. Wang, E. Iwaniczko, M. R. Page et al., "Effective interfaces in silicon heterojunction solar cells," in Proceedings of the 31st IEEE Photovoltaic Specialists Conference and Exhibition, pp. 955-958, January 2005.

[18] M. Kondo, H. Fujiwara, and A. Matsuda, "Fundamental aspects of low-temperature growth of microcrystalline silicon," Thin Solid Films, vol. 430, no. 1-2, pp. 130-134, 2003. 

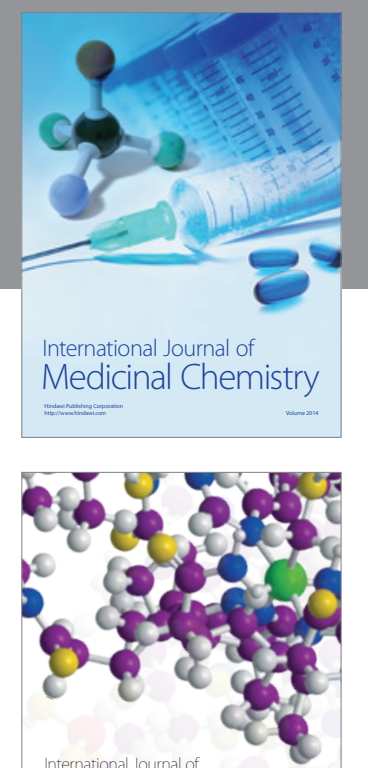

\section{Carbohydrate} Chemistry

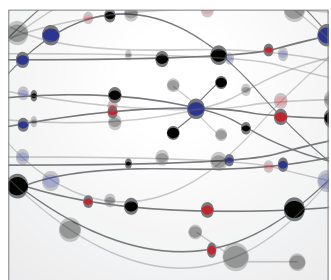

The Scientific World Journal
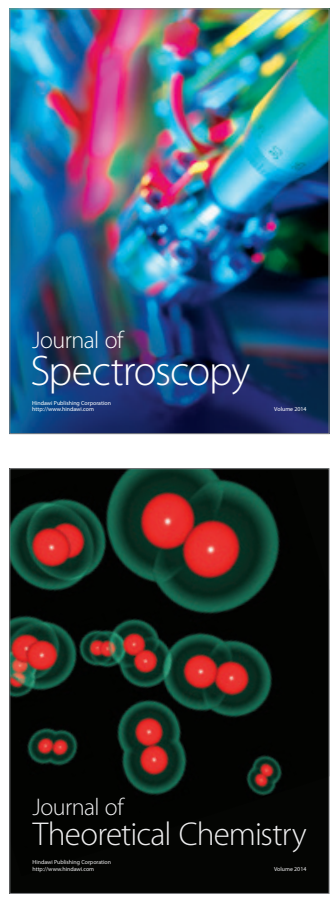
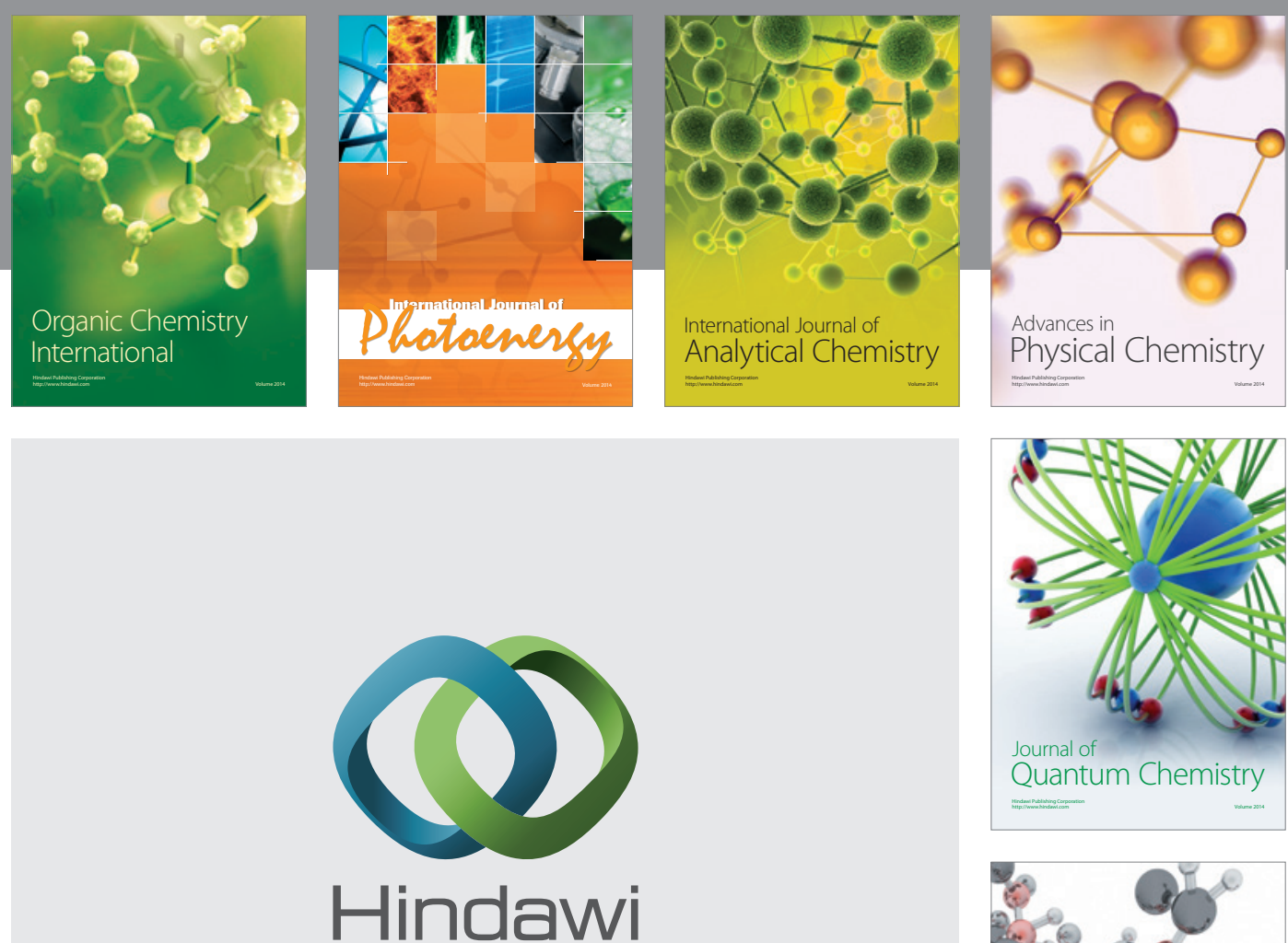

Submit your manuscripts at

http://www.hindawi.com

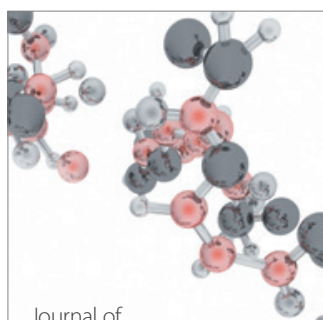

Analytical Methods

in Chemistry

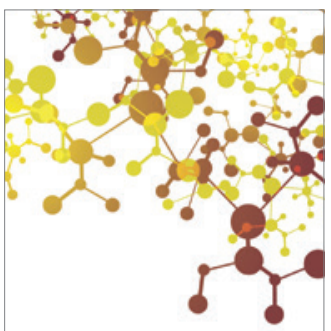

Journal of

Applied Chemistry

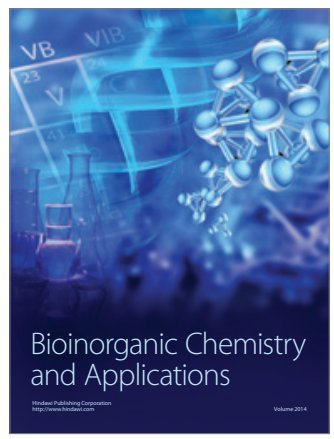

Inorganic Chemistry
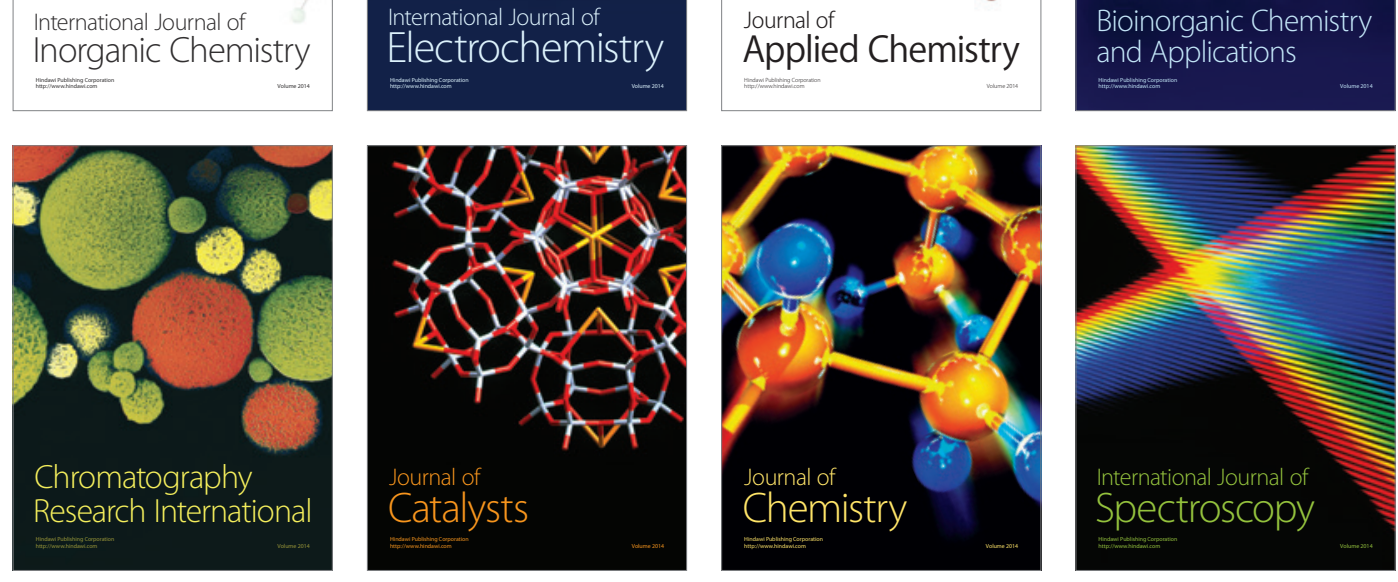